Sayed M. Derayea' / Dalia M. Nagy'

\title{
Application of a xanthene dye, eosin Y, as spectroscopic probe in chemical and pharmaceutical analysis; a review
}

\footnotetext{
${ }^{1}$ Department of Analytical Chemistry, Faculty of Pharmacy, Minia University, Minia 61519, Egypt, E-mail: sayed.derayea@gmail.com
}

\section{Abstract:}

Eosin $\mathrm{Y}(\mathrm{EY})$ is an acidic xanthene dye which is mainly used in food stuff and biological staining. Various analytical methods have been reported for the utility of this dye in the quantitative determination of several pharmaceutical compounds, heavy metals in addition to some surfactants and proteins. Most of the applied methods were based on the formation of association complexes between eosin $Y$ and the target analytes in buffered aqueous solutions. The present article represents a comprehensive review for the use of eosin $\mathrm{Y}$ as a probe in analytical chemistry.

Keywords: eosin Y, fluorimetry, heavy metal analysis, pharmaceutical analysis, spectroscopy

DOI: $10.1515 /$ revac-2017-0020

Received: September 17, 2017; Accepted: April 19, 2018

\section{Introduction}

Eosin Y (2-(2,4,5,7-tetrabromo-6-oxido-3-oxo-3H-xanthen-9-yl)benzoate) is an acidic dye that belongs to the xanthene group, which has a yellowish-red color with green fluorescence (Figure 1). Other names of eosin $Y$ are bromoeosine, eosin yellowish, bromofluoresceic acid, Acid Red 87, C.I. 45380 and D\&C Red No. 22. It is used as a coloring agent in food, cosmetics, pharmaceuticals and textiles. Eosin $\mathrm{Y}$ is often used as a counterstain in biological tissues. The hematoxylin-eosin staining is most frequently used for staining histological material. The nuclei will appear blue to dark violet in color by hematoxylin, and the eosin Y solution will stain the cytoplasm and intercellular substances red-orange.<smiles>O=c1c(Br)cc2c(-c3ccccc3Cl)c3cc(Br)c(Cl)c(Br)c3oc-2c1Br</smiles>

Figure 1: Chemical structure of eosin Y.

Almost all of the reported analytical method utilizing eosin reaction are based on the formation of an association complex between the dye and the analyte, with few exceptions (Srividya \& Balasubramanian, 1997; Liang, Deng \& Tan, 2015). The reaction was carried out mainly in slightly acidic medium. Therefore, the mechanism of complex formation will be discussed based on such media. According to the $\mathrm{pH}$ of the solution, eosin can exist in different forms (Figure 2) which can be represented by the following equation:

$$
\mathrm{H}_{3} \mathrm{R}^{+} \rightleftarrows \mathrm{H}_{2} \mathrm{R} \rightleftarrows \mathrm{HR}^{-} \rightleftarrows \mathrm{R}^{2-}
$$


<smiles>O=C(O)c1ccccc1C1c2cc(Br)c(O)c(Br)c2Oc2c1cc(Br)c(O)c2Br</smiles>

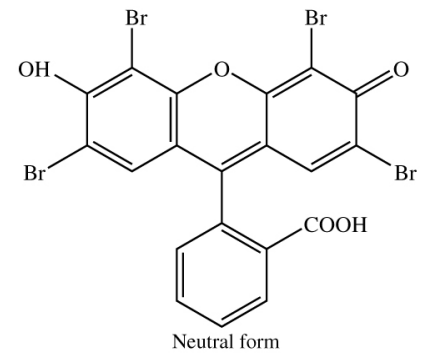<smiles>O=C(O)c1ccccc1-c1c2cc(Br)c(=O)c(Br)c-2oc2c(Br)c([O-])c(Br)cc12</smiles><smiles>C=CC</smiles><smiles></smiles>

Figure 2: The changes of the structure of eosin $\mathrm{Y}$ molecule based on the $\mathrm{pH}$ of the medium.

where R represents the anionic part of eosin Y. The reported (Batistela et al. 2011) values for $\mathrm{pK}_{\mathrm{a} 1}, \mathrm{pK}_{\mathrm{a} 2}$ and $\mathrm{pK}_{\mathrm{a} 3}$ of eosin $\mathrm{Y}$ were 2.10, 2.85 and 4.95, respectively. In a weak acidic medium (pH3.0-4.5), eosin Y exists mainly in the monovalent anionic form $\left(\mathrm{HR}^{-}\right)$. However, there are two possibilities for the formation of the monovalent anion of eosin, either by ionization of the hydroxyl or carboxylic groups. The ionization of the carboxylic group occurred first in fluorescein (eosin analogue without bromine substitutions), followed by hydroxyl group. But in the case of eosin $Y$, the presence of two strong electron withdrawing bromine atoms close to the hydroxyl group reduces the charge density at the oxygen atom of the hydroxyl moiety. As a result, the hydroxyl group tends to dissociate more easily than the carboxylic group. Therefore, eosin monovalent anion is formed by the ionization of the hydroxyl group. The complex formation occurs between eosin anion and the protonated analyte through the electrostatic attraction and hydrophobic forces as shown in Figure 3.

A<smiles>C[N+](O)([AlH2])Oc1c(Br)cc2c(-c3ccccc3C(=O)O)c3cc(Br)c(=O)c(Br)c-3oc2c1Br</smiles>

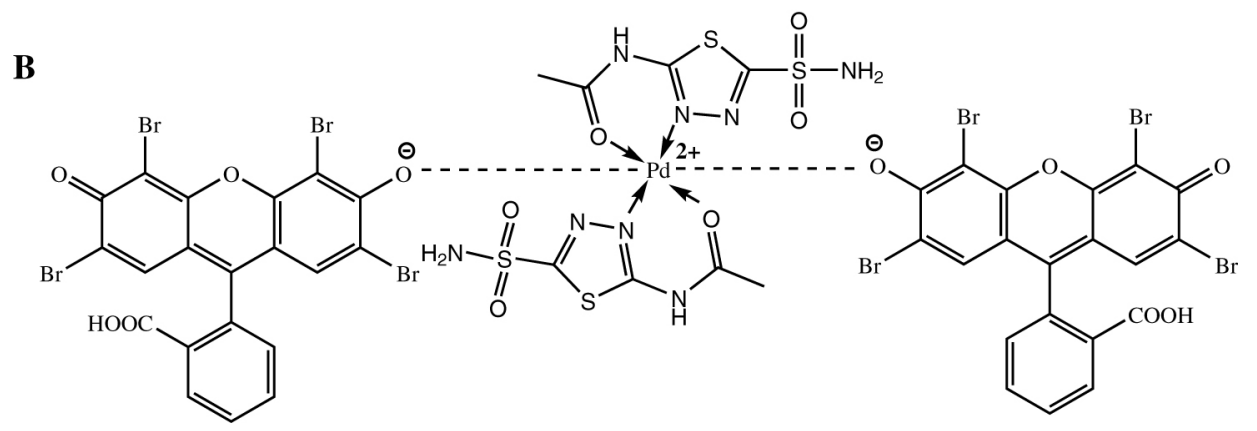

Figure 3: Chemical structures of (A) the binary complex formed between eosin $\mathrm{Y}$ and fluoxetine, and (B) ternary complex between eosin, palladium and acetazolamide.

In most cases, the composition of the formed binary complex was in the ratio of 1:1, eosin:compounds. However, in some rare cases, a complex containing 2:1, drug:eosin, was formed due to the presence of two active basic centers in the drug such as azithromycin (Walash et al. 2007) and succinylcholine (Ayad et al. 2018). In the case of ternary complexes, the target analytes form chelates with metal ions followed by further complexation of the formed chelates with eosin anion. A presentation for the structures of both binary and ternary complexes 
is shown in Figure 3. Obviously, the complex formation is accompanied by a distinct change in the absorption spectrum, fluorescence quenching and change in the resonance Rayleigh scattering spectra of eosin Y. All these changes could be employed for the construction of various quantitative techniques for the determination of the involved analytes.

\section{Discussion}

As an analytical reagent, eosin $\mathrm{Y}$ has been extensively used as ion-pairing agents for the spectrophotometric determination of some important pharmaceutical compounds with or without extraction. In addition, it was utilized in combination with metal ions for the determination of many drugs or heavy metals via ternary complex formation. The following sections summarize almost all the reported methods which applied eosin $Y$ as analytical probe.

\section{Spectrophotometric methods}

\section{Binary}

Binary complex formation with eosin was incorporated in the spectrophotometric determination of several pharmaceutical compounds (Table 1). The solution was slightly acidic ( $\mathrm{pH}$ 2.2-4.0) and the absorbance was measured at wavelengths in the range of $540-552 \mathrm{~nm}$. The majority of the formed complexes were freely soluble in water and therefore, the extraction with an organic solvent or the addition of a surfactant was not required (Kovacs-Hadady \& Fabian, 1998; El-Brashy, El-Sayed Metwally \& El-Sepai, 2004; Walash et al. 2007; 2010; Li et al., 2011; Walash et al., 2011; Ammar, El-Brashy \& Al-Sahly, 2014; Hussein, Fares \& El-Kosasy, 2014; Ayad et al., 2018; Naggar et al., 2017; El-Masry et al., 2018). However, in a few cases (Gazy et al., 2002; Derayea et al., 2012; Derayea, 2014; El-Hay, El-Mammli \& Shalaby, 2016), it was necessary to enhance the water solubility of the complex through the addition of non ionic surfactant such as methyl cellulose.

Table 1: The reported spectrophotometric methods for the determination of pharmaceutical compounds based on the binary complex formation with eosin.

\begin{tabular}{|c|c|c|c|c|c|}
\hline Drug & Matrix & $\begin{array}{l}\text { Linear } \\
\text { range } \\
(\mu \mathrm{g} / \mathrm{ml})\end{array}$ & $\begin{array}{l}\text { LOD } \\
(\mu \mathrm{g} / \mathrm{ml})\end{array}$ & Surfactant & References \\
\hline \multirow{4}{*}{$\begin{array}{l}\text { Erythromycin, azithromycin, } \\
\text { clarithromycin and } \\
\text { roxithromycin }\end{array}$} & \multirow{4}{*}{$\begin{array}{l}\text { Pharmaceutical } \\
\text { formulations and } \\
\text { biological fluids }\end{array}$} & $2.0-20$ & 0.17 & \multirow[t]{4}{*}{-} & \multirow[t]{4}{*}{ (Walash et al. 2007) } \\
\hline & & $1.0-15$ & 0.15 & & \\
\hline & & $3.0-30$ & 0.28 & & \\
\hline & & $2.0-25$ & 0.25 & & \\
\hline Succinylcholine & Ampoules & $0.5-15$ & 0.12 & - & (Ayad et al. 2018) \\
\hline Benzalkonium chloride & Eye drops & $0.7-8.5$ & - & - & $\begin{array}{l}\text { (Kovacs-Hadady } \\
\text { and Fabian 1998) }\end{array}$ \\
\hline Verapamil & $\begin{array}{l}\text { Tablet and human } \\
\text { serum samples }\end{array}$ & $0.6-4.0$ & 0.18 & - & (Li et al. 2011) \\
\hline \multirow{3}{*}{$\begin{array}{l}\text { Levofloxacin, norfloxacin and } \\
\text { ciprofloxacin }\end{array}$} & Tablets and spiked & $2.0-8.0$ & 0.15 & \multirow[t]{3}{*}{-} & (El-Brashy, El-Sayed \\
\hline & human urine & $2.0-8.0$ & 0.14 & & Metwally \& El-Sepai, \\
\hline & & $2.0-8.0$ & 0.14 & & 2004) \\
\hline \multirow[t]{2}{*}{ Tizanidine and orphenadrine } & Pharmaceutical & $0.5-8.0$ & 0.10 & \multirow[t]{2}{*}{-} & \multirow[t]{2}{*}{ (Walash et al. 2011) } \\
\hline & formulations & $1.0-12$ & 0.30 & & \\
\hline Azelastine & Dosage forms & $0.5-15$ & 0.13 & - & (El-Masry et al. 2018) \\
\hline Metoclopramide & Dosage forms & $1.0-10$ & 0.34 & - & (Naggar et al. 2017) \\
\hline $\mathrm{CTAB}^{*}$ & Waste water & $0.2-14$ & - & - & $\begin{array}{l}\text { (Hussein, Fares \& } \\
\text { El-Kosasy, 2014) }\end{array}$ \\
\hline Dothepine & Tablets and capsules & $1.0-10$ & 0.18 & - & (Walash et al. 2010) \\
\hline Doxazosin & Tablets & $2.0-14$ & 0.39 & - & $\begin{array}{l}\text { (Ammar, El-Brashy } \\
\text { \& Al-Sahly, 2014) }\end{array}$ \\
\hline \multirow{4}{*}{$\begin{array}{l}\text { Cetirizine, fexofenadine, } \\
\text { loratadine and acrivastine }\end{array}$} & \multirow[t]{4}{*}{ Dosage forms } & $8.0-24$ & 1.30 & \multirow{4}{*}{$\mathrm{MC}^{*}$} & \multirow[t]{4}{*}{ (Gazy et al. 2002) } \\
\hline & & $6.0-20$ & 0.58 & & \\
\hline & & $3.0-10$ & 0.57 & & \\
\hline & & $3.0-15$ & 0.64 & & \\
\hline Mebeverine & Dosage forms & $1.0-12$ & 0.53 & $\mathrm{MC}^{*}$ & (Derayea 2014) \\
\hline
\end{tabular}




\begin{tabular}{llllll} 
Amlodipine and nicardipine & Pharmaceutical & $5.0-60$ & 1.80 & $\mathrm{MC}^{*}$ & (Derayea et al. 2012) \\
& formulation & $10-60$ & 1.10 & & \\
Clemastine, desloratadine, & Pharmaceutical & $1.25-11.25$ & 0.72 & $\mathrm{MC}^{*}$ & (El-Hay, El-Mammli \\
losartan and moxepril & formulation & $0.31-2.81$ & 0.90 & & \& Shalaby, 2016) \\
& & $2.5-20$ & 0.82 & & \\
& & $1.25-15$ & 0.75 & & \\
\hline
\end{tabular}

${ }^{*} \mathrm{CTAB}$ is cetyltrimethyl ammonium bromide and $\mathrm{MC}$ is methylcellulose.

\section{Methods based on ternary complex}

\section{Determination of pharmaceutical compounds}

Ternary complex formation was applied for the spectrophotometric determination of many drug candidates (Table 2). In contrast to binary complexes, many of the formed ternary complexes had low water solubility. Therefore, several approaches were tried to solve this problem. The first approach was performed through extraction of the formed complex with an organic solvent. Perindopril (Abdellatef, Ayad \& Taha, 1999; Rahman \& Rahman, 2011), ramipril (Abdellatef, Ayad \& Taha, 1999; Ayad et al., 2002), enalapril (Ayad et al. 2002) and carbinoxamine (Ramadan and Mandil 2006) were complexed with eosin and zinc (for perindopril) or copper (for all drugs) followed by extraction of the complex with chloroform and measurement of the absorbance of the organic layer at 510-538 $\mathrm{nm}$. Another way to overcome the low solubility of the complex was achieved through the addition of nonionic surfactants, such as methyl cellulose (Fujita et al., 1987; el Walily, Belal \& Bakry, 1996; Ayad et al., 2003; El-Enany, 2004; Krebs, Starczewska \& Leszczyńska, 2006; Abdellatef, 2007; El-Didamony, 2007; Omar, 2010; Al-Tamimi, 2013) or polyvinyl alcohol (Mori et al. 1986). The addition of surfactants increased the complex stability and prevented its precipitation. As a result, the extraction step was omitted and the measurements were carried out directly in the aqueous solution. Thus, the simplicity of the procedure was greatly enhanced, and the environmental safety of the methods was improved. However, in some cases, the addition of the surfactant adversely affected the reproducibility of the methods. Therefore, an alternative approach was followed through keeping the analyte concentration at maximum dilution before adding the dye solution and mixing well before the addition of the acidic buffer. By this procedure, the complex stability was greatly increased, with complete prevention of precipitate formation, and maximum precision was achieved (Kelani, Bebawy \& Abdel-Fattah, 1999; Moustafa, 2000).

Table 2: Non-extractive spectrophotometric methods for the determination of pharmaceutical compounds based on the formation of ternary complex with eosin and metal ions in the presence or absence of methylcellulose as a surfactant.

\begin{tabular}{|c|c|c|c|c|c|}
\hline Drug & Matrix & $\begin{array}{l}\text { Linear } \\
\text { range } \\
(\mu \mathrm{g} / \mathrm{ml})\end{array}$ & $\begin{array}{l}\text { LOD } \\
(\mu \mathrm{g} / \mathrm{ml})\end{array}$ & Metal ion & References \\
\hline Sparfloxacin & Dosage forms & $1.6-16$ & - & Pd (II) & (El-Didamony 2007) \\
\hline $\begin{array}{l}\text { Hydrochlorothiazide, } \\
\text { indapamide and xipamide }\end{array}$ & Dosage forms & $\begin{array}{l}8.0-40 \\
8.0-40 \\
8.0-32\end{array}$ & $\begin{array}{l}0.46 \\
0.41 \\
0.35\end{array}$ & Lead (II) & (Omar 2010) \\
\hline Ramipril & Tablets & $20-80$ & - & Copper & (Abdellatef 2007) \\
\hline Ciprofloxacin and norfloxacin & Tablets & $\begin{array}{l}3.0-10 \\
3.0-10\end{array}$ & - & $\operatorname{Pd}(\mathrm{II})$ & $\begin{array}{l}\text { (el Walily, Belal \& } \\
\text { Bakry, 1996) }\end{array}$ \\
\hline Gemifloxacin & Dosage forms & $1.0-10$ & 0.16 & Pd (II) & (Al-Tamimi 2013) \\
\hline $\begin{array}{l}\text { Chlorpromazine, thiamine, } \\
\text { lincomycin, ofloxacin and } \\
\text { theophylline }\end{array}$ & $\begin{array}{l}\text { Pharmaceutical } \\
\text { preparations }\end{array}$ & $0-6.36$ & - & $\operatorname{Pd}(\mathrm{II})$ & (Fujita et al. 1987) \\
\hline Timolol and enalapril & $\begin{array}{l}\text { Pharmaceutical } \\
\text { formulations }\end{array}$ & $\begin{array}{l}0.16-1.6 \\
8.0-56\end{array}$ & - & Pd (II) & (Ayad et al. 2003) \\
\hline Gliclazide & Dosage forms & $0.5-4.0$ & 0.05 & Pd (II) & (El-Enany 2004) \\
\hline Bezafibrate & Dosage forms & $0.06-0.3$ & - & $\operatorname{Pd}(\mathrm{II})$ & $\begin{array}{l}\text { (Krebs, Starczewska } \\
\text { \& Leszczyńska, } \\
\text { 2006) }\end{array}$ \\
\hline Minocycline* & Capsules & $0-40$ & - & Gallium & (Mori et al. 1986) \\
\hline $\begin{array}{l}\text { Astemizole\#, terfenadine\# and } \\
\text { flunarizine\# }\end{array}$ & Dosage forms & $\begin{array}{l}4.1-37.6 \\
11.8-47.2 \\
2.4-19.1\end{array}$ & - & Lead (II) & $\begin{array}{l}\text { (Kelani, Bebawy \& } \\
\text { Abdel-Fattah, 1999) }\end{array}$ \\
\hline
\end{tabular}




\begin{tabular}{|c|c|c|c|c|c|}
\hline $\begin{array}{l}\text { Lansoprazole\# and } \\
\text { pantoprazole\# }\end{array}$ & $\begin{array}{l}\text { Pharmaceutical } \\
\text { formulations }\end{array}$ & $\begin{array}{l}3.7-16.6 \\
4.3-25.9\end{array}$ & - & $\begin{array}{l}\text { Copper } \\
\text { (II) }\end{array}$ & (Moustafa 2000) \\
\hline
\end{tabular}

*Polyvinyl alcohol was used as surfactant.

\#Methylcellulose was not used.

\section{Determination of heavy metals}

Some heavy metals were spectrophotometrically determined through ternary complex formation using counter ions and eosin $\mathrm{Y}$ with a limit of detection down to $0.005 \mu \mathrm{g} \mathrm{m} \mathrm{m}^{-1}$. Copper (Yen et al. 1989) was reacted with neo-cuproin and eosin Y. The formed colored associate was extracted with chloroform and measured at 544 $\mathrm{nm}$. This system was used to determine the contents of trace copper in some tablets and injections. Similarly, lead (Szczepaniak and Juskowiak 1987) was determined through its reaction with cryptand (2.2.2) and eosin Y followed by extraction with chlorobenzene. A non-extractive spectrophotometric method was reported for iron (Hashem, Seleim \& El-Zohry, 2010) in pharmaceutical and water samples through its interaction with 5-(4-nitrophenylazo) salicylic acid in an acidic medium and measuring the absorbance at $545 \mathrm{~nm}$. In the determination of mercury (I1) (Mudakavi 1984) with phenanthroline and eosin, the solubility of the formed ternary complex was enhanced by the addition of gelatine solution, and the absorbance of the aqueous solution was measured at $552 \mathrm{~nm}$.

\section{Indirect spectrophotometric method}

Thiamine (Srividya and Balasubramanian 1997) in pharmaceutical preparations was determined based on the interaction of thiamine with a known excess of silver ions in a buffered medium of $\mathrm{pH}$ 9.0. The unreacted silver ions were estimated by the formation of an ion-pair complex with eosin $\mathrm{Y}$ and the absorbance was measured at $550 \mathrm{~nm}$.

\section{Spectrofluorimetric methods}

\section{Extractive spectrofluorimetric methods}

Extractive spectrofluorimetric methods were reported for some drugs based on either binary or ternary complex formation with eosin Y. Binary complex formation was applied for the determination of citalopram hydrobromide (Azmi et al. 2015) and doxepin hydrochloride (Rahman, Siddiqui \& Azmi, 2009) in commercial dosage forms. The method was based on the formation of an ion-pair complex between the drug and eosin $\mathrm{Y}$ in the presence of acetate buffer (at $\mathrm{pH} 3.4$ for citalopram and $\mathrm{pH} 4.52$ for doxepin). The formed complexes were extracted into dichloromethane and the fluorescence intensity was measured at $554 \mathrm{~nm}$ (excitation at $259 \mathrm{~nm}$ ) for citalopram and at $567 \mathrm{~nm}$ after excitation at $464 \mathrm{~nm}$ for doxepin. Labetalol (Rahman and Haque 2008) was determined in commercial tablets and human urine samples through ternary complex with zinc (II) and eosin. The complex was extracted with chloroform and measured at $452 \mathrm{~nm}$ after excitation at $317 \mathrm{~nm}$. These methods were linear over concentrations of 2.0-26.0, 0.1-0.8 and 0.5-4.0 $\mu \mathrm{g} \mathrm{ml}^{-1}$ with limits of detection of $0.12,0.003$ and $0.08 \mu \mathrm{g} \mathrm{ml}^{-1}$ for citalopram hydrobromide, doxepin hydrochloride and labetalol, respectively.

Highly sensitive extractive spectrofluorimetric methods were reported for some heavy metals based on the formation of ternary complex between the metal cation, cryptand 2.2.1 and the eosinate counter ion. The formed complexes were extracted with 1,2-dichloroethane and their fluorescence intensities were measured. Using the previous procedure, the following metal ions were determined: lead (Gomis et al. 1988), cadmium (Gomis et al. 1989), chromium (III) (García and Gomis 1997), mercury (Andrés, Fuente \& Blanco, 1993) and thallium (Andrés García and Blanco Gomis 2002). The same principle was applied for the simultaneous determination of lead and cadmium (Gomis and Garcia 1990), lead and mercury (Andres, Fuente \& Blanco, 1994) and strontium and calcium (Andrés, Fuente \& Blanco, 1992) by sequential extraction of the ternary ion-association complexes formed between the cations, a cryptand as the ligand and eosin. Ligands, other than cryptand, were applied in the determination of some heavy metals (Haddad, Alexander \& Smythe, 1976; Sanz-Medel et al., 1984; Afonso, Santana \& Montelongo, 1986; Oue, Kimura \& Shono, 1988; Talio et al., 2009) using the same technique. These methods are summarized in Table 3. The detection limits of metal ions were in the range of $0.5-3.0 \mathrm{ng} \mathrm{ml}^{-1}$. 
Table 3: Extractive spectrofluorimetric methods for some heavy metals through ternary complex formation with eosin $Y$ and ligands other than cryptand.

\begin{tabular}{|c|c|c|c|c|}
\hline Metal & $\mathrm{pH}$ & Ligand & Organic solvent & References \\
\hline Cobalt (II) & pH 5.6 & $\begin{array}{l}\text { Pyridine-2-aldehyde-2- } \\
\text { pyridylhydrazone }\end{array}$ & $\begin{array}{l}\text { Chloroform/acetone } \\
\text { mixture }\end{array}$ & $\begin{array}{l}\text { Haddad, } \\
\text { Alexander \& } \\
\text { Smythe, 1976) }\end{array}$ \\
\hline Zinc (II) & $\begin{array}{l}\text { Acetate buffer }(\mathrm{pH} \\
5.5)\end{array}$ & $\begin{array}{l}\text { Pyrocatechol-1-aldehyde } \\
\text { 2-pyridylhydrazone }\end{array}$ & $\begin{array}{l}50 \% \text { ethanol/water } \\
\text { mixture }\end{array}$ & $\begin{array}{l}\text { (Afonso, Santana } \\
\text { \& Montelongo, } \\
\text { 1986) }\end{array}$ \\
\hline Lead (II) & & 18-crown-6 & & $\begin{array}{l}\text { (Sanz-Medel et al. } \\
\text { 1984) }\end{array}$ \\
\hline Silver (I) & $\mathrm{pH} 8.6$ & Benzothiacrown ether & Dichloromethane & $\begin{array}{l}\text { (Oue, Kimura \& } \\
\text { Shono, 1988) }\end{array}$ \\
\hline Cadmium & Tris buffer pH 7.6 & o-phenanthroline & PONPE $7.5^{*}$ & (Talio et al. 2009) \\
\hline
\end{tabular}

*The complex was extracted into polyoxyethylene (7.5) nonylphenyl ether (PONPE 7.5) using cloud point extraction.

\section{Fluorescence quenching methods}

The aqueous solution of eosin $\mathrm{Y}$ showed native fluorescence at about $545 \mathrm{~nm}$ after excitation at $301 \mathrm{~nm}$. The addition of basic compounds (containing mainly amino groups) to the reagent solution dramatically reduced the fluorescence intensity of eosin Y. The fluorescence quenching was due to the formation of ion pair complexes between the basic compounds and eosin Y (Figure 4). Based on this fact, many analytical procedures were constructed for the determination of several pharmaceutical compound (de Vries, Ruben \& Arends, 1991; Gazy et al., 2002; Belal et al., 2008; Liu et al., 2008; Arici \& Kilinc, 2010; Walash et al., 2010; Ibrahim et al., 2011; Omar et al., 2011; Gan et al., 2012; Kaur \& Malik, 2013; Ammar, El-Brashy \& Al-Sahly, 2014; Derayea, 2014; Hussein, Fares \& El-Kosasy, 2014; Wahba, El-Enany \& Belal, 2015; Derayea et al. 2016; 2016; Hammad, Omar \& Eltoukhi, 2016; Ayad et al., 2018; Azmi et al., 2017; Theia'a, Dhamra \& Al-Ghabsha, 2017; Derayea, Omar \& Abu-hassan, 2018) through the formation of binary complexes (Table 4). In many cases, metal ions (lead, copper, zinc and palladium) were chelated with the analyte. These chelates can induce the fluorescence quenching of eosin $Y$ upon the formation of ternary complex (Figure 4). Table 5 summarizes the use of ternary complex formation for determination of some basic compound (Omar, 2010; Abdellatef, 2007; el Walily, Belal \& Bakry, 1996; AlTamimi, 2013; Kelani, Bebawy \& Abdel-Fattah, 1999; Attia \& Omar, 2016; Wu et al., 2017; Shi et al., 2016) through fluorescence quenching of eosin Y. Stern-Volmer equation was applied in several studies (Liu et al., 2008; Gan et al., 2012; Kaur \& Malik, 2013; Wahba, El-Enany \& Belal, 2015; Azmi et al., 2017) to investigate the mechanism of the fluorescence quenching due to the complex formation. All the mentioned reports agreed that the quenching process followed static mechanism as the quenching constants were greater than the highest reported value for dynamic quenching. Further evidence for the static mode are the changes in the absorption spectra of the dye that accompanied the complex formation. In static quenching, the quencher reacts with a fluorescent agent in the ground state to form a non-fluorescent or a weakly fluorescent complex. The complex formation occurred through electrostatic attraction, hydrophobic forces and/or hydrogen bonding. 


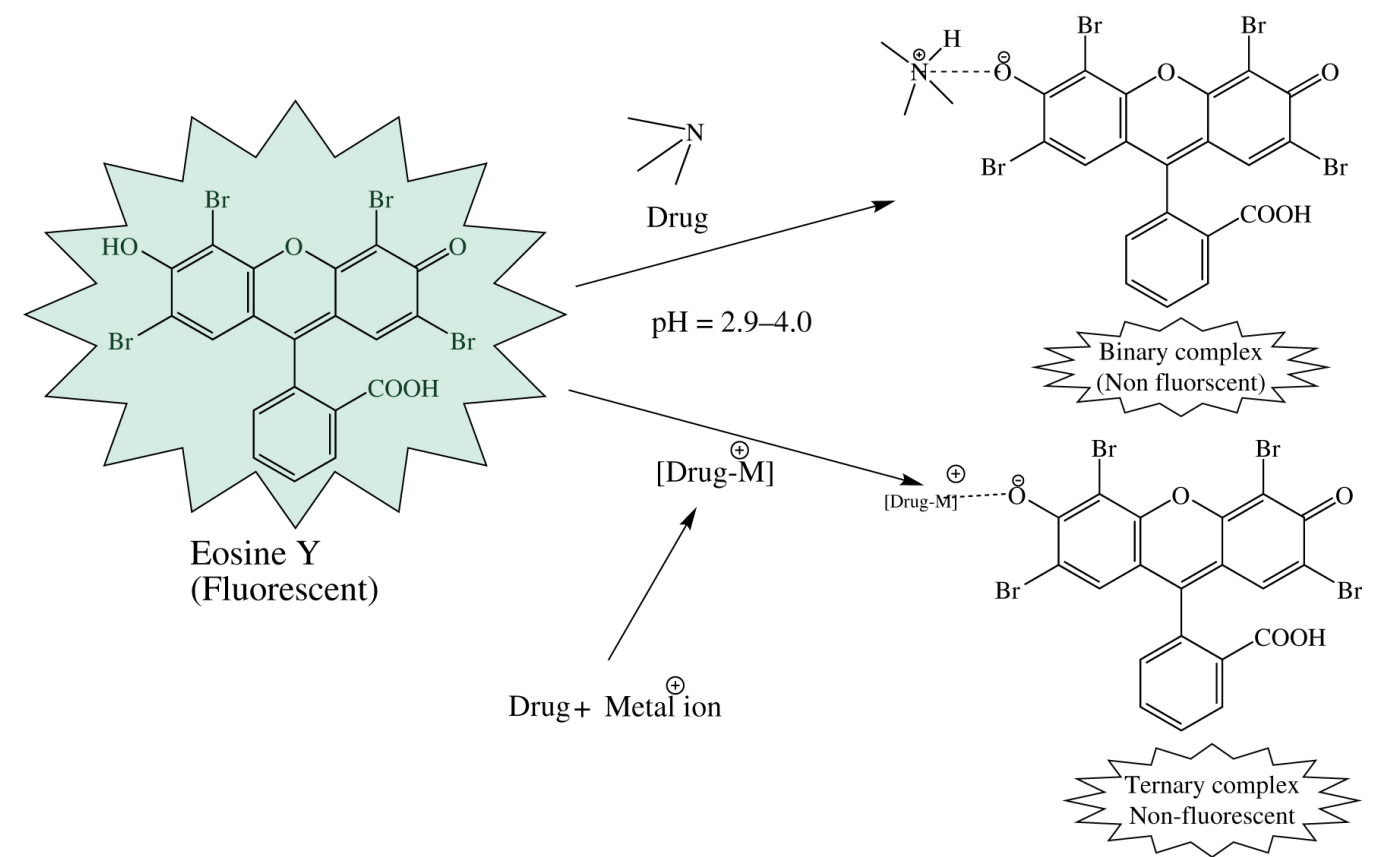

Figure 4: Fluorescence quenching of eosin $\mathrm{Y}$ by either binary or ternary complexes formation. Metal ion can be copper $\left(\mathrm{Cu}^{2+}\right)$, lead $\left(\mathrm{Pb}^{2+}\right)$, zinc $\left(\mathrm{Zn}^{2+}\right)$ or palladium $\left(\mathrm{Pd}^{2+}\right)$.

Table 4: Reported fluorescence quenching methods for pharmaceutical analysis based on binary complex formation with eosin $Y$.

\begin{tabular}{|c|c|c|c|c|c|}
\hline Drugs & Matrix & $\begin{array}{l}\text { Linear } \\
\text { range } \\
(\mu \mathrm{g} / \mathrm{ml})\end{array}$ & $\begin{array}{l}\text { LOD } \\
(\mu \mathrm{g} / \mathrm{ml})\end{array}$ & $\begin{array}{l}\lambda_{\mathrm{em}} / \lambda_{\mathrm{ex}} \\
(\mathrm{nm})\end{array}$ & References \\
\hline $\begin{array}{l}\text { Cetyltrimethyl ammonium } \\
\text { bromide }\end{array}$ & $\begin{array}{l}\text { Industrial waste } \\
\text { water }\end{array}$ & $2.9-14.5$ & - & $500 / 304$ & $\begin{array}{l}\text { (Hussein, Fares \& } \\
\text { El-Kosasy, 2014) }\end{array}$ \\
\hline Dothiepin & Dosage forms & $0.3-8.0$ & 0.11 & $543 / 304$ & (Walash et al. 2010) \\
\hline Doxazosin & Tablets & $1.0-10$ & 0.079 & $570 / 340$ & $\begin{array}{l}\text { (Ammar, El-Brashy } \\
\text { \& Al-Sahly, 2014) }\end{array}$ \\
\hline Succinylcholine & Ampoules & $0.05-1.0$ & 0.012 & $550 / 480$ & (Ayad et al. 2018) \\
\hline $\begin{array}{l}\text { Cetirizine, fexofenadine, } \\
\text { loratadine and acrivastine }\end{array}$ & Dosage forms & $\begin{array}{l}3.0-10 \\
2.0-10 \\
4.0-10 \\
2.0-10\end{array}$ & $\begin{array}{l}- \\
- \\
- \\
-\end{array}$ & $550 / 310$ & (Gazy et al. 2002) \\
\hline Mebeverine* & Dosage forms & $0.2-3.5$ & 0.11 & $540 / 390$ & (Derayea 2014) \\
\hline Chlorhexidine & Saliva & $1.0-15$ & 0.80 & $541 / 301$ & $\begin{array}{l}\text { (de Vries, Ruben \& } \\
\text { Arends, 1991) }\end{array}$ \\
\hline Olanzapine and fluphenazine & Dosage forms & $\begin{array}{l}0.05-1.0 \\
0.10-1.0\end{array}$ & $\begin{array}{l}0.012 \\
0.018\end{array}$ & $547 / 323$ & (Belal et al. 2008) \\
\hline Carbazochrome & Biological fluids & $0.03-1.5$ & 0.009 & $545 / 301$ & (Gan et al. 2012) \\
\hline Ebastine & Dosage forms & $0.1-1.0$ & 0.021 & $553 / 457$ & (Ibrahim et al. 2011) \\
\hline $\begin{array}{l}\text { Losartan, irbesartan, } \\
\text { telmisartan and valsartan }\end{array}$ & $\begin{array}{l}\text { Pharmaceutical } \\
\text { tablets }\end{array}$ & $\begin{array}{l}0.8-8.0 \\
0.8-7.0 \\
0.9-4.0 \\
1.0-8.0\end{array}$ & $\begin{array}{l}0.203 \\
0.110 \\
0.112 \\
0.132\end{array}$ & $546 / 310$ & (Omar et al. 2011) \\
\hline $\begin{array}{l}\text { Betaxolol, carvedilol, labetalol, } \\
\text { nebivolol and propranolol }\end{array}$ & Dosage forms & $\begin{array}{l}0.1-2.5 \\
0.1-2.5 \\
0.15-2.5 \\
0.15-2.5 \\
0.05-2.2\end{array}$ & $\begin{array}{l}0.028 \\
0.024 \\
0.057 \\
0.046 \\
0.016\end{array}$ & $545 / 301$ & (Derayea et al. 2016) \\
\hline Fluoxetine and paroxetine & $\begin{array}{l}\text { Pharmaceutical } \\
\text { formulations }\end{array}$ & $\begin{array}{l}0.2-2.4 \\
0.1-2.4\end{array}$ & $\begin{array}{l}0.066 \\
0.036\end{array}$ & $545 / 301$ & (Derayea et al. 2016) \\
\hline $\begin{array}{l}\text { Amitriptyline and } \\
\text { clomipramine }\end{array}$ & Tablets & $\begin{array}{l}0.08-2.0 \\
0.06-2.0\end{array}$ & $\begin{array}{l}0.017 \\
0.016\end{array}$ & $550 / 310$ & $\begin{array}{l}\text { (Kaur and Malik } \\
\text { 2013) }\end{array}$ \\
\hline $\begin{array}{l}\text { Bleomycin } \mathrm{A}_{5} \text { and bleomycin } \\
\mathrm{A}_{2}\end{array}$ & $\begin{array}{l}\text { Human serum and } \\
\text { urine }\end{array}$ & $\begin{array}{l}0.12-2.5 \\
0.09-2.0\end{array}$ & $\begin{array}{l}0.04 \\
0.02\end{array}$ & $527 / 542$ & (Liu et al. 2008) \\
\hline
\end{tabular}




\begin{tabular}{|c|c|c|c|c|c|}
\hline Tetracycline and terbutaline & Dosage forms & $\begin{array}{l}0.50-18 \\
0.05-5.0\end{array}$ & $\begin{array}{l}0.53 \\
0.24\end{array}$ & $545 / 350$ & $\begin{array}{l}\text { (Theia'a, Dhamra \& } \\
\text { Al-Ghabsha, 2017) }\end{array}$ \\
\hline Sunitinib & Dosage forms & $0.80-5.0$ & 0.041 & $547 / 350$ & $\begin{array}{l}\text { (Arici and Kilinc } \\
\text { 2010) }\end{array}$ \\
\hline $\begin{array}{l}\text { Almotriptan, rizatriptan, } \\
\text { sumatriptan and zolmitriptan }\end{array}$ & $\begin{array}{l}\text { Pharmaceutical } \\
\text { preparations and } \\
\text { biological fluid }\end{array}$ & $\begin{array}{l}0.07-1.0 \\
0.20-1.0 \\
0.20-1.0 \\
0.10-1.0\end{array}$ & $\begin{array}{l}0.019 \\
0.041 \\
0.055 \\
0.032\end{array}$ & $543 / 301$ & $\begin{array}{l}\text { (Hammad, Omar \& } \\
\text { Eltoukhi, 2016) }\end{array}$ \\
\hline Clindamycin & Dosage forms & $0.2-2.0$ & 0.13 & $482 / 555$ & $\begin{array}{l}\text { (Wahba, El-Enany \& } \\
\text { Belal, 2015) }\end{array}$ \\
\hline Atomoxetine and fluvoxamine & Capsules and tablets & $\begin{array}{l}0.2-2.2 \\
0.3-2.2\end{array}$ & $\begin{array}{l}0.06 \\
0.08\end{array}$ & $545 / 302$ & $\begin{array}{l}\text { (Derayea, Omar \& } \\
\text { Abu-hassan, 2018) }\end{array}$ \\
\hline Chlorpheniramine & Tablets & $1.0-8.0$ & 0.30 & $544 / 258$ & (Azmi et al. 2017) \\
\hline
\end{tabular}

*Methyl cellulose was added to enhance the aqueous solubility of the complex.

Table 5: Reported fluorescence quenching methods based on ternary complex formation with eosin $\mathrm{Y}$ in the presence or absence of methyl cellulose.

\begin{tabular}{|c|c|c|c|c|c|}
\hline Drug & $\begin{array}{l}\text { Linear range } \\
(\mu \mathrm{g} / \mathrm{ml})\end{array}$ & $\begin{array}{l}\text { LOD } \\
(\mu \mathrm{g} / \mathrm{ml})\end{array}$ & Metal ion & $\begin{array}{l}\lambda_{\mathrm{em}} / \lambda_{\mathrm{ex}} \\
(\mathrm{nm})\end{array}$ & References \\
\hline $\begin{array}{l}\text { Hydrochlorothiazide, } \\
\text { indapamide and xipamide }\end{array}$ & $\begin{array}{l}0.05-0.25 \\
0.05-0.25 \\
0.05-0.25\end{array}$ & $\begin{array}{l}0.014 \\
0.013 \\
0.012\end{array}$ & Lead (II) & $545 / 462$ & (Omar 2010) \\
\hline Ramipril & $2.0-8.0$ & - & Copper (II) & $543 / 300$ & (Abdellatef 2007) \\
\hline Ciprofloxacin and norfloxacin & $\begin{array}{l}0.035-0.07 \\
0.025-0.05\end{array}$ & $\begin{array}{l}- \\
-\end{array}$ & Palladium (II) & $545 / 336$ & $\begin{array}{l}\text { (el Walily, Belal \& } \\
\text { Bakry, 1996) }\end{array}$ \\
\hline Gemifloxacin & $0.6-4.0$ & 0.11 & Palladium (II) & $544 / 337$ & (Al-Tamimi 2013) \\
\hline $\begin{array}{l}\text { Chlorpromazine, thiamine, } \\
\text { lincomycin, ofloxacin and } \\
\text { theophylline }\end{array}$ & $0-2.4$ & - & Palladium (II) & $545 / 462$ & (Fujita et al. 1987) \\
\hline $\begin{array}{l}\text { Astemizole, terfenadine and } \\
\text { flunarizine }\end{array}$ & $0.94-7.1$ & - & Lead (II) & $462 / 545$ & $\begin{array}{l}\text { (Kelani, Bebawy \& } \\
\text { Abdel-Fattah, 1999) }\end{array}$ \\
\hline Thioridazine and flupentixol & $\begin{array}{l}0.5-3.0 \\
0.5-3.0\end{array}$ & $\begin{array}{l}0.06 \\
0.07\end{array}$ & Lead (II) & $517 / 462$ & $\begin{array}{l}\text { (Attia and Omar } \\
\text { 2016) }\end{array}$ \\
\hline Guanine* & $0.5-17.5$ & 0.22 & Copper (II) & $539 / 480$ & (Shi et al. 2016) \\
\hline Quizalofop-p-ethyl & $0.04-1.0$ & 0.02 & Palladium (II) & $540 / 519$ & (Wu et al. 2017) \\
\hline
\end{tabular}

*Methylcellulose was not used.

\section{Catalytic spectrofluorimetric method}

An indirect spectrofluorimetric method using eosin as a highly sensitive fluorescent probe for clenbuterol hydrochloride (Liu et al. 2014) detection has been designed. The method was based on its catalytic effect on sodium iodate oxidating eosin $Y$. The linear range was $0.02 \times 10^{-18}-24 \times 10^{-18} \mathrm{~g} \mathrm{ml}^{-1}$ with detection limit of $6.8 \mathrm{zg} \mathrm{ml}^{-1}$ $\left(10^{-21} \mathrm{~g} \mathrm{ml}^{-1}\right)$.

\section{Switch "off-on" of eosin Y fluorescence}

Perfluorooctane sulfonate (PFOS) (Liang, Deng \& Tan, 2015) was determined in aqueous solution based on the "off-on" switch of eosin Y/polyethyleneimine (PEI) fluorescence system. In Britton-Robinson buffer solution ( $\mathrm{pH}$ 7.0), eosin Y reacted with protonated PEI to form complex which resulted in a strong quenching of the native fluorescence of eosin Y. The fluorescence was recovered by the addition of PFOS due to the higher affinity of PEI to PFOS than eosin Y. The recovered fluorescence intensity was proportional to the concentration of PFOS in the range of $0-1.0 \mu \mathrm{g} \mathrm{ml}^{-1}$ with the limit of detection of $0.0075 \mu \mathrm{g} \mathrm{ml} l^{-1}$. 


\section{Solid surface fluorescence (SSF)}

Zinc (Talio et al. 2015) traces were determined in beverages and water samples by solid surface fluorescence. In Tris buffer ( $\mathrm{pH} 7.5$ ), zinc ion was complexed with o-phenanthroline and eosin and adsorbed in a piece of filter paper. The filter paper was used as a solid support in conventional quartz cuvette and the fluorescence intensity was measured at $440 \mathrm{~nm}\left(\lambda_{\text {ex }}=340 \mathrm{~nm}\right)$. The linear range of the method was $1.29-4.5 \mathrm{pg} \mathrm{ml}^{-1}(\mathrm{LOD}$, $0.36 \mathrm{pg} \mathrm{ml}^{-1}$ ). The nickel (Talio et al. 2010) level in human urine of smokers and non-smokers' subjects was checked using SSF. Nylon membranes previously treated with eosin were applied to absorb the metal ions and the fluorescence emission was measured at $547 \mathrm{~nm}\left(\lambda_{\mathrm{ex}}\right.$ at $\left.515 \mathrm{~nm}\right)$. The linear metal concentration was in the range of $0.44-410 \mathrm{pg} \mathrm{ml}^{-1}$ (LOD, $0.13 \mathrm{pg} \mathrm{ml}^{-1}$ ). Nickel and cadmium (Talio et al. 2017) were simultaneously determination in tobacco after chemofiltration on nylon membrane. In phosphate buffer ( $\mathrm{pH} 7)$, the metals were complexed with eosin and carbon nanotubes dispersed in sodium dodecyl sulfate solution and the solution was filtered through the nylon membrane. The solid support selectively retained $\mathrm{Ni}$ (II) and its fluorescence intensity was measured at $545 \mathrm{~nm}\left(\lambda_{\text {ex }}=515 \mathrm{~nm}\right)$. The $\mathrm{Cd}$ (II) content in the filtrate was determined by adjusting the $\mathrm{pH}$ to 5.0 with acetate buffer and the fluorescence was measured at $565 \mathrm{~nm}\left(\lambda_{\text {ex }}=540 \mathrm{~nm}\right)$. The calibration curves were linear in the range of $0.058-29.35$ and $0.124-56.20 \mathrm{ng} \mathrm{ml}^{-1}$ with detection limits of 19 and $41 \mathrm{pg} \mathrm{ml}^{-1}$ for $\mathrm{Ni}(\mathrm{II})$ and $\mathrm{Cd}(\mathrm{II})$, respectively.

\section{Solid substrate-room temperature phosphorimetry (SS-RTP)}

Trace of clenbuterol hydrochloride (Liu et al. 2009) was determined with high sensitivity (detection limit, 0.021 $\mathrm{zg} \mathrm{spot}{ }^{-1}$; corresponding concentration, $0.52 \times 10^{-21} \mathrm{~g} \mathrm{ml}^{-1}$ ) by SS-RTP based on its catalytic effect on the oxidation of eosin $\mathrm{Y}$ with sodium periodate. Oxidation of eosin was accompanied by a sharp quenching of the room temperature phosphorescence signal of eosin. Another SS-RTP has been reported for some bioactive matters (alpha-fetoprotein variant, alkaline phosphatase and glucose) (Liu et al. 2009) based on their adsorption affinity to eosin self-ordered ring. The ring was formed by the reaction of eosin with polyamide membrane in the presence of cetyl trimethyl ammonium bromide and ammonia water. Detection limits of this method were 0.040, 0.045 and $0.090 \mathrm{fg} \mathrm{spot}^{-1}$ for alpha-fetoprotein variant, alkaline phosphatase and glucose. As shown in Table 6, SS-RTP was the most sensitive technique which applied Eosin Y as a reagent.

Table 6: Comparison between the sensitivity of the reported methods for the determination of both organic compounds and heavy metals.

\begin{tabular}{|c|c|c|}
\hline Methods & $\begin{array}{l}\text { LOD } \\
(\mathrm{g} / \mathrm{ml})\end{array}$ & References \\
\hline $\begin{array}{l}\text { Organic compounds including pharmaceuticals } \\
\text { - Non-extractive spectrophotometry (binary complex) } \\
\text { - Non-extractive spectrophotometry (ternary complex) } \\
\text { - Extractive spectrofluorimetry } \\
\text { - Fluorescence quenching (binary complex) } \\
\text { - Fluorescence quenching (ternary complex) } \\
\text { - Switch “off-on" of eosin Y fluorescence } \\
\text { - Resonance Rayleigh scattering } \\
\text { - Flow injection chemiluminescence } \\
\text { - Catalytic spectrofluorimetry } \\
\text { - Solid substrate-room temperature phosphorimetry } \\
\text { Heavy metals } \\
\text { - Spectrophotometry (ternary complex) } \\
\text { - Extractive spectrofluorimetry (ternary complex) } \\
\text { - Solid surface fluorescence (ternary complex) }\end{array}$ & $\begin{array}{l}0.10 \times 10^{-6} \\
50 \times 10^{-9} \\
3.0 \times 10^{-9} \\
9.0 \times 10^{-9} \\
20 \times 10^{-9} \\
7.5 \times 10^{-9} \\
0.95 \times 10^{-9} \\
0.23 \times 10^{-12} \\
6.8 \times 10^{-21} \\
0.52 \times 10^{-21} \\
5.0 \times 10^{-9} \\
0.5 \times 10^{-9} \\
0.13 \times 10^{-12}\end{array}$ & $\begin{array}{l}\text { (Walash et al. 2011) } \\
\text { (El-Enany 2004) } \\
\text { (Rahman, Siddiqui \& Azmi, 2009) } \\
\text { (Gan et al. 2012) } \\
\text { (Wu et al. 2017) } \\
\text { (Liang, Deng \& Tan, 2015) } \\
\text { (Li et al. 2011) } \\
\text { (Wang, Zhao \& Gao, 2014) } \\
\text { (Liu et al. 2014) } \\
\text { (Liu et al. 2009) } \\
\text { (Hashem, Seleim \& El-Zohry, 2010) } \\
\text { (Andrés, Fuente \& Blanco, 1992) } \\
\text { (Talio et al. 2010) }\end{array}$ \\
\hline
\end{tabular}

\section{Chemiluminescence method}

Streptomycin (Du et al. 2013) in rat plasma was determined by a chemiluminescence (CL)-based reaction. In the alkaline medium, N-bromosuccinimide-eosin system had a weak CL signal which was greatly enhanced by the addition of streptomycin. Ferulic acid (Shen et al. 2013) was also determined by flow injection chemiluminescence. The method was based on the significant enhancement of ferulic acid on the CL signal of the N-bromobutanimide-eosin-chromium (II) chloride system in alkaline solution. Lercanidipine (Wang, Zhao \& 
Gao, 2014) was determined with high sensitivity using post-chemiluminescence (PCL) method combined with a flow injection technique. PCL reaction was performed by injecting lercanidipine solution into the CL reaction mixture of N-chlorosuccinimide with alkaline eosin $\mathrm{Y}$ (as the CL reagent) in the presence of cetyltrimethylammonium bromide as a surfactant. The linear concentration ranges were 0.008-1.0, 0.0004-0.1 and 0.0007-3.0 $\mu \mathrm{g} \mathrm{ml}^{-1}$ with detection limits of $2.25,0.28$ and $0.23 \mathrm{ng} \mathrm{ml}^{-1}$ for streptomycin, ferulic acid and lercanidipine, respectively.

\section{Resonance Rayleigh scattering}

The formation of eosin $\mathrm{Y}$ association complex (binary or ternary types) was accompanied not only by change in the absorption spectrum, quenching of the eosin Y fluorescence, but also the large-scale enhancement of resonance Rayleigh scattering (RRS) and the appearance of new RRS spectra. The enhancement of RRS was attributed to the enlargement of the molecular volume as a result of increasing the molecular weight, increasing the molecular rigidity and planarity, and enhancement of the hydrophobicity as a result of complex formation (Li et al., 2017; Tian et al., 2014). The complex formation restricts the free rotation of the dye molecule, which increased its molecular rigidity and planarity. In addition, before the complex formation, the drug was positively charged, while eosin $Y$ was negatively charged, so each of them can be easily hydrated and dissolved in water. However, when they reacted with each other, their charges are neutralized. Consequently, the produced ion-association complex is electrically neutral and hence the hydrophobicity is enhanced. The increase in the scattering intensity was directly proportional to the drug concentrations. RRS was used in the determination of bleomycin $A_{5}$ and bleomycin $A_{2}$ (Liu et al. 2007) in serum and urine samples with detection limits of 17 and $18 \mathrm{ng} \mathrm{ml}^{-1}$, respectively, verapamil (Li et al. 2011) in acetate buffer solution ( $\mathrm{pH}$ 3.2) with linear range of $0.003-4.0 \mu \mathrm{g} \mathrm{ml}^{-1}$ (LOD, $0.95 \mathrm{ng} \mathrm{ml}^{-1}$ ), albendazole (Tian et al. 2014) in Britton-Robinson buffer solution ( $\mathrm{pH}$ 3.3) with linear range of $0.2-3.2 \mu \mathrm{g} \mathrm{ml}^{-1}$ (LOD, $6.93 \mathrm{ng} \mathrm{ml}^{-1}$ ) and polyvinyl pyrrolidone (Yu et al. 2010) in acetate buffer $(\mathrm{pH} 3.2)$ with linear range of $0.01-0.16 \mu \mathrm{g} \mathrm{ml}^{-1}$ (LOD, $0.029 \mu \mathrm{g} \mathrm{ml}^{-1}$ ). Additionally, the new resonance Rayleigh scattering were appeared at 324, 620, 324, 356 and $276 \mathrm{~nm}$ for bleomycin $\mathrm{A}_{5}$, bleomycin $\mathrm{A}_{2}$, verapamil, albendazole and polyvinyl pyrrolidone, respectively. Linezolid (Thakkar, Gevriya \& Mashru, 2014) and acetazolamide ( $\mathrm{Li}$ et al. 2017) in acetate buffer ( $\mathrm{pH} 4$ ) reacted with eosin and palladium to form ternary ion association complexes in the presence of methyl cellulose. The RRS was measured at 538 and $298 \mathrm{~nm}$ for linezolid and acetazolamide, respectively. The linear concentration ranges were $0.01-0.5$ and $0.014-2.5 \mu \mathrm{g} \mathrm{ml} \mathrm{m}^{-1} \mathrm{~A}$ ternary complex was formed between metallothioneins (Xiao et al. 2015), eosin Y and sodium dodecyl benzene sulfate in Britton-Robinson buffer ( $\mathrm{pH}$ 3.9). The RRS of the complex was measured at $366 \mathrm{~nm}$ and the method had a linear concentration range of $0.04-14.0 \mu \mathrm{g} \mathrm{ml}^{-1}$.

\section{Atomic absorption spectroscopy}

Ramipril (Abdellatef, Ayad \& Taha, 1999; Ayad et al., 2002), perindopril (Abdellatef, Ayad \& Taha, 1999) and enalapril (Ayad et al. 2002) were determined indirectly through complex formation with copper (II) and eosin in aqueous buffered solutions. The formed ternary complexes were extracted into chloroform and the copper content of the organic extracts were determined by atomic absorption spectroscopy.

\section{Conclusion}

In this article, the use of eosin $Y$ as an analytical probe was reviewed. The applications included mainly pharmaceutical analysis, in addition to several heavy metals, some surfactants and few proteins. These methods were based mainly on the formation of either binary or ternary complexes between the target analyte and eosin. Spectrofluorimetry was the most widely used technique and represents about 50\% of all the reported spectroscopic methods (Figure 5). One half of the spectrofluorimetric methods were based on the quenching effect of the analyte on the native fluorescence of the dye. Fluorescence quenching methods are fairly sensitive (LOD down to $9 \mathrm{ng} \mathrm{ml}^{-1}$ ) and were applied to a wide range of pharmaceutical compounds and surfactants. Although RRS provided a more sensitive method for quantitative determination down to $0.95 \mathrm{ng} \mathrm{ml}^{-1}$, it was used in very few articles. In spite of the extreme sensitivity of the SS-RTP (Table 6) with a detection limit in the zepto-gram level $\left(10^{-21} \mathrm{~g}\right)$, only two applications were reported using this technique. Other minor methods included atomic absorption spectroscopy $(2 \%)$ and chemiluminescence $(3 \%)$. 


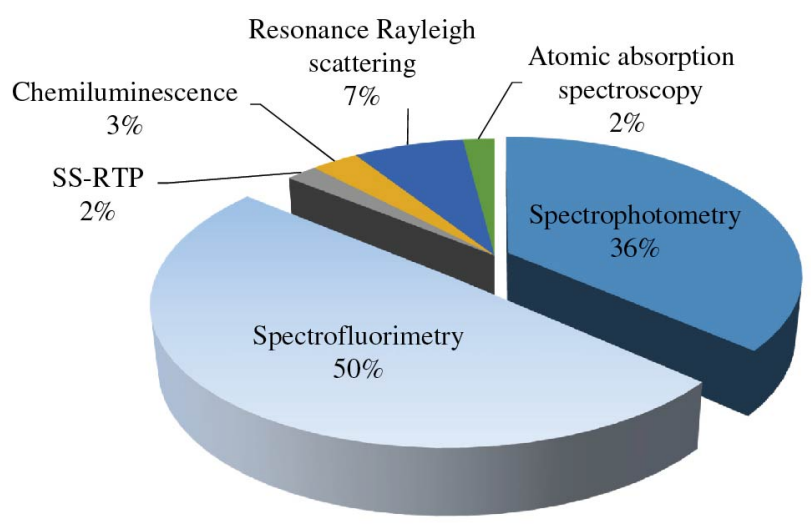

Figure 5: Summary for the reported spectroscopic method utilizing eosin $\mathrm{Y}$ as a reagent. SS-RTP is solid substrate-room temperature phosphorimetry.

Conflict of interest: The authors of the paper declare no conflict of interest in publishing this paper.

\section{References}

Abdellatef, H. E. Spectrophotometric and Spectrofluorimetric Methods for the Determination of Ramipril in its Pure and Dosage Form. Spectrochim. Acta A 2007, 66, 701-706.

Abdellatef, H. E.; Ayad, M. M.; Taha, E. A. Spectrophotometric and Atomic Absorption Spectrometric Determination of Ramipril and Perindopril Through Ternary Complex Formation with Eosin and Cu(II). J. Pharm. Biomed. Anal. 1999, 18, 1021-1027.

Afonso, A. M.; Santana, J. J.; Montelongo, F. G. Spectrofluorimetric Determination of Zinc with Pyrocatechol-1-Aldehyde 2-Pyridylhydrazone. Analyst 1986, 111, 327-329.

Al-Tamimi, S. A. Spectrophotometric and Spectrofluorimetric Methods for the Determination of Cemifloxacin Mesylate in its Pure and Dosage Forms Using Eosin. Asian ]. Chem. 2013, 25, 9272.

Ammar, R. A.; El-Brashy, A. M.; Al-Sahly, T. N. Spectrophotometric and Spectrofluorometric Determination of Doxazosin Mesylate in Tablets via Eosin Y. Asian ]. Chem. 2014, 26, 57.

Arici, M.; Kilinc, E. Validated Spectrofluorimetric Method for the Determination of Sunitinib Malate, Dye Complexation Approach for a Novel Anticancer Drug. Acta Pharm. Sci 2010, 52, 468-484.

Andrés Carcía, E.; Blanco Comis D. Extraction-Spectrofluorimetric Determination of Thallium Using Cryptand Ethers. Anal. Lett. 2002, 35 , 2337-2346.

Andrés, E.; Fuente, E.; Blanco, D. Sequential Extraction-Spectrofluorimetric Determination of Mercury Using Cryptand Ethers. Anal. Lett. 1993, 26, 1037-1048.

Andrés, E.; Fuente, E.; Blanco, D. Sequential Extraction-Spectrofluorimetric Determination of Strontium and Calcium Using Cryptand Ethers. Anal. Lett. 1992, 25, 339-352.

Andres, E.; Fuente, E.; Blanco, D. Sequential Extraction-Spectrofluorimetric Determination of Lead and Mercury Using Cryptand Ethers. Anal Lett. 1994, 27, 775-784.

Attia, T. Z.; Omar, M. A. Spectrofluorimetric Determination of Thioridazine and Flupentixol in Dosage Forms; Application to Content Uniformity Test. Luminescence 2016, 31, 1091-1097.

Ayad, M. M.; Shalaby, A. A.; Abdellatef, H. E.; Hosny, M. M. Spectrophotometric and AAS Determination of Ramipril and Enalapril Through Ternary Complex Formation. J. Pharm. Biomed. Anal. 2002, 28, 311-321.

Ayad, M. M.; Shalaby, A.; Abdellatef, H. E.; Hosny, M. M. Spectrophotometric Methods for Determination of Enalapril and Timolol in Bulk and in Drug Formulations. Anal. Bioanal. Chem. 2003, 375, 556-560.

Ayad, M. M.; Belal, F.; Hosney, M. M.; Abo El Abass, S.; Elsayed, N. Spectroscopic Determination of Succinylcholine in Dosage Forms Using Eosin Y. Luminescence 2018, 33, 376-381.

Azmi, S. N.; Al-Fazari, A.; Al-Badaei, M.; Al-Mahrazi, R. Utility of Eosin Y as a Complexing Reagent for the Determination of Citalopram Hydrobromide in Commercial Dosage Forms by Fluorescence Spectrophotometry. Luminescence 2015, 30, 1352-1359.

Azmi, S. N. H.; Al-Hadhrami, S. S. K.; Al-Marhoubi, B. M. R.; Al-Sulaimi, S. S. S.; Al-Shamoosi, Z. D. S. Development and Validation of Fluorescence Spectrophotometric Method: Quantitation of Chlorpheniramine Maleate in Pharmaceutical Formulations. J. Mol. Liq. 2017, 243, 750-760.

Batistela, V. R.; Pellosi, D. S.; de Souza, F. D.; da Costa, W. F.; de Oliveira Santin, S. M.; de Souza, V. R.; Caetano, W.; de Oliveira, H. P. M.; Scarminio, I. S.; Hioka, N. pKa Determinations of Xanthene Derivates in Aqueous Solutions by Multivariate Analysis Applied to UV-Vis Spectrophotometric Data. Spectrochim. Acta A 2011, 79, 889-897.

Belal, F.; El-Brashy, A.; El-Enany, N.; El-Bahay, N. Spectrofluorometric Determination of Olanzapine and Fluphenazine Hydrochloride in Pharmaceutical Preparations and Human Plasma Using Eosin: Application to Stability Studies. J. AOAC Int. 2008, 91, 1309-1317.

de Vries, J.; Ruben, J.; Arends, J. Determination of Chlorhexidine in Saliva and in Aqueous Solutions. Caries Res. 1991, 25, 410-414. 
Derayea, S. M. An Application of Eosin Y for the Selective Spectrophotometric and Spectrofluorimetric Determination of Mebeverine Hydrochloride. Anal. Methods 2014, 6, 2270-2275.

Derayea, S. M.; Askal, H. F.; Abdel-Megeed, O. H.; El Hamd, M. A. Spectrophotometric Determination of Amlodipine and Nicardipine in Pharmaceutical Formulations via Binary Complex Formation with Eosin Y. J. Appl. Pharm. Sci. 2012, 2, 84-89.

Derayea, S. M.; Omar, M. A.; Abdel-Lateef, M. A.-K., Hassan, A. I. Development and Validation of a New Spectrofluorimetric Method for the Determination of Some Beta-Blockers Through Fluorescence Quenching of Eosin Y. Application to Content Uniformity Test. Open Chem. 2016, 14, 258-266.

Derayea, S. M.; Omar, M. A.; Abu-hassan, A. A. Studying the Association Complex Formation of Atomoxetine and Fluvoxamine with Eosin Y and its Application in Their Fluorimetric Determination. R. Soc. Open Sci. 2018, 5, 170943.

Derayea, S.; Omar, M.; Mohammed, B.; Ali, R. Sensitive Spectrofluorimetric Protocol for the Determination of Fluoxetine and Paroxetine Through Binary Complex Formation with Eosin Y. Anal. Chem. Lett. 2016, 6, 508-517.

Du, B.; Li, H.; Jin, J.; Wang, T.; Li, Y.; Shen, G.; Li, X. Chemiluminescence Determination of Streptomycin in Pharmaceutical Preparation and its Application to Pharmacokinetic Study by a Flow Injection Analysis Assembly. Spectrochim. Acta Part A Mol. Biomol. Spectrosc. 2013, 115, $823-828$.

el Walily, A. F.; Belal, S. F.; Bakry, R. S. Spectrophotometric and Spectrofluorimetric Estimation of Ciprofloxacin and Norfloxacin by Ternary Complex Formation with Eosin and Palladium(II). J. Pharm. Biomed. Anal. 1996, 14, 561-569.

El-Didamony, A. M. Spectrophotometric Determination of Sparfloxacin in Pharmaceutical Preparations by Ternary Complex Formation with Pd (II) and Eosin. Anal. Lett. 2007, 40, 2708-2720.

El-Brashy, A. M.; El-Sayed Metwally, M.; El-Sepai, F. A. Spectrophotometric Determination of Some Fluoroquinolone Antibacterials by Binary Complex Formation with Xanthene Dyes. Farmaco 2004, 59, 809-817.

El-Enany, N. Spectrophotometric Determination of Cliclazide in Pharmaceuticals and Biological Fluids Through Ternary Complex Formation with Eosin and Palladium (II). Farmaco 2004, 59, 63-69.

El-Hay, S. S. A.; El-Mammli, M. Y.; Shalaby, A. A. Determination of Clemastine Hydrogen Fumarate, Desloratadine, Losartan Potassium and Moxepril HCl Through Binary Complex Formation with Eosin. Arab. J. Chem. 2016, 9, S541-S547.

El-Masry, A. A.; Hammouda, M. E.; El-Wasseef, D. R.; El-Ashry, S. M. Validated Spectroscopic Methods for Determination of Anti-histaminic Drug Azelastine in Pure Form: Analytical Application for Quality Control of its Pharmaceutical Preparations. Spectrochim. Acta A 2018, 191, $413-420$.

Fujita, Y.; Mori, I.; Fujita, K.; Nakahashi, Y.; Tanaka, T. Determination of Chlorpromazine, Thiamine, Lincomycin, Ofloxacin and Theophylline by Ternary Complex Formation with Eosin and Palladium(II). Chem. Pharm. Bull. 1987, 35, 5004-5009.

Gan, X.; Liu, S.; Liu, Z.; Hu, X.; Cui, Z.; Wang, Y. Determination of Carbazochrome by Fluorescence Quenching Method. Spectrochim. Acta Part A Mol. Biomol. Spectrosc. 2012, 97, 161-166.

García, E. A.; Comis, D. B. Speciation Analysis of Chromium Using Cryptand Ethers. Analyst 1997, 122, 899-902.

Gazy, A. A.; Mahgoub, H.; El-Yazbi, F. A.; El-Sayed, M. A.; Youssef, R. M. Determination of Some Histamine H1-Receptor Antagonists in Dosage Forms. J. Pharm. Biomed. Anal. 2002, 30, 859-867.

Comis, D. B.; Abrodo, P. A.; Lobo, A. M.; Medel, A. S. Fluorimetric Determination of Ultratraces of Lead by lon-Pair Extraction with Cryptand 2.2.1 and Eosin. Talanta 1988, 35, 553-558.

Comis, D. B.; Alonso, E. F.; Garcia, E. A.; Abrodo, P. A. Ion-Pair Extraction and Fluorimetric Determination of Cadmium with Cryptand 2.2.1 and Eosin. Talanta 1989, 36, 1237-1241

Comis, D. B.; Garcia, E. A. Sequential Extraction-Spectrofluorometric Determination of Lead and Cadmium Using Cryptands. Analyst 1990, 115, 89-91.

Haddad, P. R.; Alexander, P. W.; Smythe, L. E. Spectrophotometric and Fluorometric Determination of Cobalt. Talanta 1976, $23,275-281$.

Hammad, M.; Omar, M.; Eltoukhi, W. Validation of Rapid and Sensitive Spectrofluorimetric Assay for Determination of Four Triptans in Pure and Dosage Forms; Application to Human Plasma and Content Uniformity Testing. Pharm. Anal. Acta 2016, 7, 2.

Hashem, E.; Seleim, M.; El-Zohry, A. M. Spectrophotometric Determination of Iron in Pharmaceutical and Water Samples by Interacting with 5-(4-nitrophenylazo) Salicylic Acid and Eosin. J. ASTM Int. 2010, 8, 1-9.

Hussein, L. A.; Fares, N. V.; El-Kosasy, A. M. Spectrophotometric, Spectrofluorimetric, and Potentiometric Assays of Cetyltrimethylammonium Bromide in Industrial Wastewater Samples. J. AOAC Int. 2014, 97, 1175-1182.

Ibrahim, F.; El-Din, M. K.; Eid, M. I.; Wahba, M. E. Validated Stability-Indicating Spectrofluorimetric Methods for the Determination of Ebastine in Pharmaceutical Preparations. Chem. Cent. J. 2011, 5, 11.

Kaur, K.; Malik, A. K. Study on the Fluorescence Quenching Reaction of Amitriptyline and Clomipramine Hydrochlorides with Eosin Y and its Analytical Application. J. Fluoresc. 2013, 23, 533-542.

Kelani, K.; Bebawy, L. I.; Abdel-Fattah, L. Determination of Astemizole, Terfenadine and Flunarizine Hydrochloride by Ternary Complex Formation with Eosin and Lead(II). J. Pharm. Biomed. Anal. 1999, 18, 985-992.

Kovacs-Hadady, K.; Fabian, I. The Determination of Benzalkonium Chloride in Eye-Drops by Difference Spectrophotometry. J. Pharm. Biomed. Anal. 1998, 16, 733-740.

Krebs, A.; Starczewska, B.; Leszczyńska, E. Spectrophotometric Determination of Bezafibrate by Ternary Complex Formation with Palladium (II) Chloride and Eosin. Anal. Lett. 2006, 39, 2453-2462.

Li, C.; Liu, S.; Liu, Z.; Hu, X. Study on the Interaction Between Verapamil Hydrochloride and Eosin Y by Absorption, Fluorescence and Resonance Rayleigh Scattering Spectra and Their Analytical Applications. J. Fluoresc. 2011, 21, 723-732.

Li, J.; Wang, J.; Chang, H.; Wei, W. Resonance Rayleigh Scattering and Resonance Nonlinear Scattering of the Palladium (II)-Acetazolamide Chelate with Eosin Y and Their Analytical Application. Spectrosc. Lett. 2017, 50, 494-500.

Liang, J.; Deng, X.; Tan, K. An Eosin Y-based "turn-on" Fluorescent Sensor for Detection of Perfluorooctane Sulfonate. Spectrochim. Acta Part A Mol. Biomol. Spectrosc. 2015, 150, 772-777.

Liu, J.; Liu, Z.; Li, W.; Huang, X.; Zeng, L.; Sha, J.; Li, F. Determination of Bioactive Matter by Affinity Adsorption Solid Substrate-Room Temperature Phosphorimetry Based on Lectin Labeled with Self-Ordered Ring of Eosin Y. J. Fluoresc 2009, 19, 73-83. 
Liu, J.; Liu, Z. B.; Huang, Q.; Lin, C. Q.; Lin, X. Highly Sensitive Fluorescent Probe for Clenbuterol Hydrochloride Detection Based on its Catalytic Oxidation of Eosine $\mathrm{Y}$ by NalO4. J. Fluoresc. 2014, 24, 1495-1501.

Liu, J.; Liu, Z.; Hu, X.; Kong, L.; Liu, S. A Highly Sensitive Resonance Rayleigh Scattering Method for the Determination of BleomycinA5 and BleomycinA2 with Some Halofluorescein Dyes. J. Pharm. Biomed. Anal. 2007, 43, 1452-1459.

Liu, J.; Liu, Z.; Hu, X.; Kong, L.; Liu, S. Fluorescence Quenching Method for the Determination of Bleomycins A5 and A2 with Halofluorescein Dyes. Luminescence $\mathbf{2 0 0 8 , 2 3 , 1 - 6 .}$

Liu, J.; Zeng, L.; Li, Z.; Gao, F.; Huang, X.; Li, F.; Lin, H. Solid Substrate-Room Temperature Phosphorimetry for the Determination of Residual Clenbuterol Hydrochloride Based on the Catalysis of Sodium Periodate Oxidizing Eosine Y. Anal. Chim. Acta 2009, 638, 69-74.

Mori, I.; Fujita, Y.; Kawabe, H.; Fujita, K.; Tanaka, T.; Kishimoto, A. Applications of Xanthene Derivatives in Analytical Chemistry. Part LVII. Spectrophotometric Determination of Minocycline Using Gallium and Eosin. Analyst 1986, 111, 1409-1412.

Moustafa, A. A. Spectrophotometric Methods for the Determination of Lansoprazole and Pantoprazole Sodium Sesquihydrate. J. Pharm. Biomed. Anal. 2000, 22, 45-58.

Mudakavi, J. R. Spectrophotometric Determination of Trace Amounts of Mercury with Phenanthroline and Eosin. Analyst 1984, 109, 15771579.

Naggar, A.; Elnasr, T.; Sayed Ali, A.; Kotb, A.; El Sayed, A. Determination of Metoclopramide Hydrochloride in Pharmaceutical Formulations Using Three Different Spectrophotometric Methods. Pharm. Anal. Acta 2017, 8, 2.

Omar, M. A. Spectrophotometric and Spectrofluorimetric Determination of Certain Diuretics Through Ternary Complex Formation with Eosin and Lead (II). J. Fluoresc. 2010, 20, 275-281.

Omar, M. A.; Abdelmageed, O. H.; Abdel-Caber, A. A.; Abdel-Megied, A. M. Spectrophotometric and Spectrofluorimetric Determination of Certain Angiotensin Receptor Blockers Through Complex Formation. J. Pharm. Sci. Res. 2011, 3, 1499-1510.

Oue, M.; Kimura, K.; Shono, T. Extraction-Spectrofluorimetric Determination of Silver lon Using Benzothiacrown Ether and Eosin. Analyst 1988, 113, 551-553.

Ramadan, A. A.; Mandil, H. Spectrophotometric Determination of Carbinoxamine Maleate in Pharmaceutical Formulations by Ternary Complex Formation with Cu(II) and Eosin. Anal. Biochem. 2006, 353, 133-137.

Rahman, N.; Haque, S. M. Spectrofluorimetric Determination of Labetalol Hydrochloride in Pharmaceutical Preparations and Urine Samples. Int. J. Biomed. Sci. IJBS 2008, 4, 140-146.

Rahman, N.; Siddiqui, S.; Azmi, S. N. Spectrofluorimetric Method for the Determination of Doxepin Hydrochloride in Commercial Dosage Forms. AAPS PharmSciTech 2009, 10, 1381-1387.

Rahman, N.; Rahman, H. Quantitative Analysis of Perindopril Erbumine in Pharmaceutical Preparations by Spectrophotometry via Ternary Complex Formation with Zn (II) and Eosin and Charge Transfer Complexation with lodine. Spectroscopy 2011, 25, 123-136.

Sanz-Medel, A.; Comis, D. B.; Fuente, E.; Jimeno, S. A. Extractive Fluorimetric Determination of Ultratraces of Lead with $18-$ Crown-6 and Eosin. Talanta 1984, 31, 515-519.

Shen, G.; Jia, X.; Jin, J.; Pang, L.; Chen, Z.; Du, B. Determination of Ferulic Acid by Flow Injection Chemiluminescence Analysis Based on Enhancement of the N-bromobutanimide-eosin- $\mathrm{CrCl}_{3}$ System in Alkaline Solution. Luminescence 2013, 28, 536-541.

Shi, H.; Cui, Y.; Cong, Y.; Feng, S. Highly Sensitive and Selective Fluorescent Assay for Cuanine Based on the Cu(2+)/Eosin Y System. Spectrochim. Acta Part A Mol. Biomol. Spectrosc. 2016, 161, 150-154.

Srividya, K.; Balasubramanian, N. Indirect Spectrophotometric Determination of Thiamine in Pharmaceutical Preparations. Chem. Pharm. Bull. 1997, 45, 2100-2103.

Szczepaniak, W.; Juskowiak, B. Extraction-Spectrophotometric Determination of Lead in Heavy Metal Salts with Cryptand (2.2.2) and Eosin. Microchim. Acta 1987, 92, 237-242.

Talio, M. C.; Luconi, M. O.; Masi, A. N.; Fernandez, L. P. Determination of Cadmium at Ultra-Trace Levels by CPE-Molecular Fluorescence Combined Methodology. J. Hazard. Mater. 2009, 170, 272-277.

Talio, M. C.; Luconi, M. O.; Masi, A. N.; Fernandez, L. P. Solid Surface Spectroscopic Methodology for Ultra-Trace Urinary Nickel Monitoring in Smokers and Non-smokers' Subjects. J. Pharm. Biomed. Anal. 2010, 52, 694-700.

Talio, M. C.; Acosta, M. G.; Acosta, M.; Olsina, R.; Fernandez, L. P. Novel Method for Determination of Zinc Traces in Beverages and Water Samples by Solid Surface Fluorescence Using a Conventional Quartz Cuvette. Food Chem. 2015, 175, 151-156.

Talio, M. C.; Alesso, M.; Acosta, M.; Wills, V. S.; Fernandez, L. P. Sequential Determination of Nickel and Cadmium in Tobacco, Molasses and Refill Solutions for e-Cigarettes Samples by Molecular Fluorescence. Talanta 2017, 174, 221-227.

Thakkar, D.; Cevriya, B.; Mashru, R. C. Study on Interaction Between Palladium-Linezolid Chelate with Eosin by Resonance Rayleigh Scattering, Second Order of Scattering and Frequency Doubling Scattering Methods Using Taguchi Orthogonal Array Design. Spectrochim. Acta A 2014, 122, 75-81.

Theia'a, N.; Dhamra, M. Y.; Al-Chabsha, T. S. Spectrofluorimetric Determination of Tetracycline and Terbutaline Sulphate in its Pure and Dosage Forms Using Eosin y Reagent. Euro Chem. Bull. 2017, 6, 336-342.

Tian, F.; Huang, W.; Yang, J.; Li, Q. Study on the Interaction Between Albendazole and Eosin Y by Fluorescence, Resonance Rayleigh Scattering and Frequency Doubling Scattering Spectra and Their Analytical Applications. Spectrochim. Acta A 2014, 126, 135-141.

Wahba, M.; El-Enany, N.; Belal, F. Application of the Stern-Volmer Equation for Studying the Spectrofluorimetric Quenching Reaction of Eosin with Clindamycin Hydrochloride in its Pure Form and Pharmaceutical Preparations. Anal. Methods 2015, 7, 10445-10451.

Walash, M. I.; Rizk, M. S.; Eid, M. I.; Fathy, M. E. Spectrophotometric Determination of Four Macrolide Antibiotics in Pharmaceutical Formulations and Biological Fluids via Binary Complex Formation with Eosin [corrected]. J. AOAC Int. 2007, 90, 1579-1587.

Walash, M. I.; Belal, F.; El-Enany, N.; Elmansi, H. Spectrophotometric and Spectrofluorimetric Methods for the Determination of Dothiepin Hydrochloride in its Pure and Dosage Forms Using Eosin. Int. J. Biomed. Sci. IJBS 2010, 6, 327-334.

Walash, M. I.; Belal, F. F.; Eid, M. I.; Mohamed, S. A. Spectrophotometric Determination of Tizanidine and Orphenadrine via Ion Pair Complex Formation Using Eosin Y. Chem. Cent. J. 2011, 5, 60.

Wang, G.; Zhao, F.; Gao, Y. Flow Injection Chemiluminescence Determination of Lercanidipine Based on N-chlorosuccinimide-Eosin Y Postchemiluminescence Reaction. Luminescence 2014, 29, 1008-1013. 
Wu, H.; Zhao, Y.; Tan, X.; Zeng, X.; Guo, Y.; Yang, J. A Convenient Method for Determination of Quizalofop-p-Ethyl Based on the Fluorescence Quenching of Eosin Y in the Presence of Pd(II). Spectrochim. Acta Part A Mol. Biomol. Spectrosc. 2017, 174, 301-306.

Xiao, X.; Xue, J.; Ding, D.; Liao, L.; Meng, X.; Liu, L.; Zhou, B.; He, B. Determination of Trace Metallothioneins at Nanogram Levels with Eosin Y by Resonance Light Scattering Method. Int. J. Environ. Anal. Chem. 2015, 95, 520-530.

Yen, J. C.; Bei, Z. Y.; Su, D. S.; Zhu, M. Extraction-Spectrophotometric Determination of Copper in Tablets and Injections of Chinese Medicine. Zhongguo Zhong Yao Za Zhi 1989, 14, 23-24, 62.

Yu, L.; Liu, Z.; Hu, X.; Kong, L.; Liu, S. Resonance Rayleigh Scattering Method for the Determination of Polyvinylpyrrolidone Using Eosin Y as the Probe. Microchim. Acta 2010, 169, 375-382. 